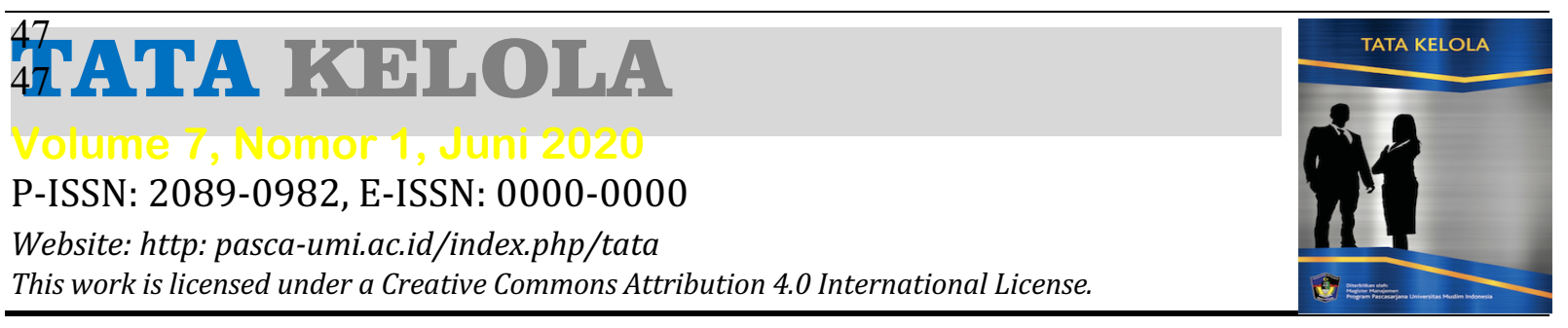

\title{
Analisis Kinerja Keuangan Pada Badan Layanan Umum (BLU) Rumah Sakit Umum
}

\author{
Nurliah Nurliah ${ }^{1}$, Abdul Rahman Mus ${ }^{2}$, Ibrahim Dani ${ }^{3}$ \\ 1,2,3, Magister Manajemen, Universitas Muslim Indonesia. \\ ${ }^{1}$ Koresponden Penulis, E-mail: nurliah.nurliah@gmail.com
}

\begin{abstract}
ABSTRAK
Tujuan penelitian ini adalah untuk menganalisis kinerja keuangan RSUP Dr. Wahidin Sudirohusodo Makassar setelah implementasi Pola Pengelolaan Keuangan Badan Layanan Umum (PPK-BLU) berdasarkan Peraturan Direktur Jenderal Perbendaharaan Nomor: PER-36/PB/2012 pada RSUP Dr. Wahidin Sudirohusodo Makassar. Data yang digunakan adalah data kuantitatif dan data kualitatif. Metode analisis yang akan digunakan oleh penulis dalam penelitian ini adalah metode analisis kuantitatif yaitu menggunakan analisis Rasio Keuangan berdasarkan Peraturan Direktur Jenderal Perbendaharaan Nomor: Per-36/PB/2012. Hasil penelitian menunjukkan bahwa: (1) hasil analisis rasio kas, rasio lancar, dan periode penagihan piutang di RSUP Dr. Wahidin Sudirohusodo Makassar selama tahun 2015-2018 tergolong kurang baik, dimana rata-rata nilai yang diperoleh dari hasil analisis rasio keuangan tersebut berada di bawah nilai kisaran maksimum berdasarkan Peraturan Direktur Jenderal Perbendaharaan Nomor: PER-36/PB/2012; (2) Hasil analisis perputaran aset tetap (PAT), imbalan atas aktiva tetap (ROA), dan imbalan ekuitas (ROE) menunjukkan kondisi keuangan RSUP Dr. Wahidin Sudirohusodo Makassar selama tahun 2015-2018 tergolong baik, dimana rata-rata nilai yang diperoleh dari hasil analisis rasio keuangan tersebut mendekati atau mencapai nilai kisaran maksimum berdasarkan Peraturan Direktur Jenderal Perbendaharaan Nomor: PER-36/PB/2012; dan (3) RSUP Dr. Wahidin Sudirohusodo Makassar yang memiliki nilai rasio keuangan dan pendapatan BLU secara keseluruhan adalah 44,7\% dengan predikat penilaian kinerja keuangan digolongkan dalam klasifikasi "cukup sehat
\end{abstract}

Kata Kunci: perputaran aktiva tetap (PAT), pengembalian aset (ROA), dan pengembalian untuk ekuitas (ROE)

\begin{abstract}
The purpose of this study was to analyze the financial performance of RSUP Dr. Wahidin Sudirohusodo Makassar after the implementation of the Financial Management Pattern of the Public Service Agency (PPKBLU) based on the Director General of the Treasury Regulation Number: PER-36 / PB / 2012 at Dr. Wahidin Sudirohusodo Makassar. The data used are quantitative data and qualitative data. The analysis method that will be used by the authors in this study is a quantitative analysis method that is using the analysis of Financial Ratios based on the Director General of Treasury Regulation Number: Per-36 / PB / 2012. The results showed that: (1) analysis of cash ratios, current ratios, and accounts receivable collection periods at RSUP Dr. Wahidin Sudirohusodo Makassar during 2015-2018 was classified as not good, where the average value obtained from the analysis of financial ratios was below the maximum range value based on the Director General of the Treasury Regulation Number: PER-36 / PB / 2012; (2) The results of analysis of fixed asset turnover (PAT), return on fixed assets (ROA), and return on equity (ROE) show the financial condition of RSUP Dr. Wahidin Sudirohusodo Makassar during 2015-2018 was classified as good, where the average value obtained from the analysis of the financial ratios approached or reached a maximum range value based on the Director General of the Treasury Regulation Number: PER-36 / PB / 2012; and (3) RSUP Dr. Wahidin Sudirohusodo Makassar, whose overall financial ratio and BLU income is $44.7 \%$ with the rating of financial performance classified as "quite healthy"
\end{abstract}

Keyword: fixed asset turnover (PAT), asset return (ROA), and return on equity (ROE) 


\section{PENDAHULUAN}

Dengan diterbitkannya Peraturan Pemerintah (PP) No. 23 Tahun 2005 tentang Pengelolaan Keuangan Badan Layanan Umum (BLU) sebagaimana diamanahkan dalam pasal 69 ayat (7) UU No. 1 Tahun 2004 tentang Perbendaharaan Negara. PP tersebut bertujuan untuk meningkatkan pelayanan publik oleh Pemerintah, karena sebelumnya tidak ada pengaturan yang spesifik mengenai unit pemerintahan yang melakukan pelayanan kepada masyarakat yang pada saat itu bentuk modelnya beraneka macam. Jenis BLU di sini antara lain rumah sakit, lembaga pendidikan, pelayanan lisensi, penyiaran, dan lain-lain.

Badan Layanan Umum (BLU) merupakan instansi di lingkungan Pemerintah yang dibentuk untuk memberikan pelayanan kepada masyarakat berupa penyediaan barang dan/atau jasa yang dijual tanpa mengutamakan mencari keuntungan dan dalam melakukan kegiatannya didasarkan pada prinsip efisiensi dan produktivitas. BLU bertujuan untuk meningkatkan pelayanan kepada masyarakat dalam rangka memajukan kesejahteraan umum dan mencerdaskan kehidupan bangsa dengan memberikan fleksibilitas dalam pengelolaan keuangan berdasarkan prinsip ekonomi dan produktivitas, dan penerapan praktek bisnis yang sehat.

Peraturan keuangan negara telah merubah mindset atau pola pikir yang lebih efisien, profesionalitas, akuntabel, dan transparan, dengan melakukan perubahan dari penganggaran tradisional menjadi penganggaran berbasis kinerja, yang membuka koridor bagi penerapan basis kinerja di lingkungan pemerintah. Dengan basis kinerja ini, arah penggunaan dana pemerintah menjadi lebih jelas dari hanya membiayai input dan proses menjadi berorientasi pada output. Perubahan ini sangat berarti mengingat kebutuhan dana yang semakin tinggi, sedangkan sumber daya yang dimiliki pemerintah terbatas (Ahmad Hag, 2009).

Tuntuntan untuk meningkatkan tata kelola yang baik (good government governance) disektor pemerintah terus meningkat seiring dengan meningkatnya kesadaran masyarakat akan hak kewarganegaraan. Penciptaan tata kelola yang baik tersebut menuntut perubahan dalam sistem manajemen keuangan pemerintah. Tuntutan tersebut juga tidak lepas dari pengaruh globalisasi yang sedang melanda dunia, yang menjadikan norma-norma tata kehidupan suatu negara sebagai bagian integral dari norma umum kehidupan dunia sehingga praktik-praktik dunia bisnis dan pemerintah suatu negara akan terpengaruh oleh norma-norma umum yang berada di negara lain.

Untuk menciptakan tata kelola yang baik pemerintah sebagai pihak eksekutif yang paling bertanggungjawab dalam pelaksanaan pemerintahan, perlu meningkatkan pelaksanaan unsur-unsur good government governance secara konsisten. Unsurunsur tata kelola yang baik tersebut antara lain Transparansi, Akuntabilitas dan Demokrasi.

Perubahan paradigma dalam sistem pengelolaan keuangan pemerintah yang paling menonjol sebagai bagian dari paket reformasi dibidang keuangan negara adalah adanya pergeseran dari sistem penganggaran tradisional kesistem penganggaran berbasis kinerja, dimana pembiayaan tidak hanya membiayai masukan (inputs) atau proses, tetapi sudah diarahkan pada pembiayaan yang membiayai hasil (outputs). 
Adanya BLU ini membuka kesempatan bagi satuan-satuan kerja pemerintah yang melaksanakan tugas operasional pelayanan publik (seperti layaknya kesehatan, pendidikan, pengelolaan kawasan, lisensi dan penyiaran) dengan lebih efektif, untuk membedakannya dari fungsi pemerintah sebagai regulator dan penentu kebijakan. Praktik ini telah berkembang luas di manca negara berupa upaya pengagenan (agencification) aktivitas yang tidak harus dilakukan oleh birokrat murni, tetapi berpotensi lebih efektif dan efisien bila diselenggarakan oleh Instansi yang dikelola bisnis (businness like).

Di lingkungan pemerintah di Indonesia, terdapat banyak satuan kegiatan yang berpotensi untuk dikelola lebih efektif melalui pola Badan Layanan Umum. Diantara mereka ada yang memperoleh imbalan dari masyarakat dalam proporsi signifikan sehubungan dengan layanan yang diberikan, dan ada pula yang bergantung sebagian besar pada dana yang disediakan oleh APBN/APBD. Kepada mereka, terutama yang selama ini mendapatkan hasil pendapatan dari layanannya dalam porsi signifikan, dapat diberikan keleluasaan dalam mengelola sumber daya untuk meningkatkan pelayanan yang diberikan.

Salah satu yang menyebabkan rendahnya mutu pelayanan di instansi pemerintah tersebut adalah rendahnya fleksibililitas pengelolaan keuangan BLU. Berdasarkan pemikiran tersebut, pemerintah memberikan sejumlah fleksibilitas untuk instansi yang menerapkan PPK-BLU. Fleksibiltas tersebut yang menganut prinsip manajemen bisnis yang sehat. Fleksibilitas BLU meliputi pengelolaan pendapatan dan belanja, pengelolaan kas, pengadaan barang/jasa, pengelolaan barang, pengelolaan piutang, utang, investasi, pemanfaatan surplus, dan remunerasi. Di samping itu, untuk mendukung manajemennya, BLU menerapkan sistem akuntansi yang berpedoman pada standar akuntansi komersial yang diterapkan oleh Ikatan Akuntan Indonesia.

Rumah Sakit Umum Pusat Dr. Wahidin Sudirohusodo Makassar, merupakan salah satu satuan kerja dibawah Kementerian Kesehatan Republik Indonesia yang telah menerapkan PPK-BLU sejak tahun 2005 berdasarkan Surat Menteri Kesehatan Nomor: 861/MENKES/VI/2005 dan Surat Keputusan Menteri Kesehatan RI Nomor: 1243/Menkes/VIII/2005, yang sebelumnya berstatus perusahaan jawatan (PERJAN). RSUP Dr. Wahidin Sudirohusodo Makassar diharapkan dapat mengalami peningkatan efisiensi dan efektivitas pelayanan jasa rumah sakit kepada masyarakat, sebagai salah satu agen pemerintah yang melakukan fungsi pelayanan masyarakat.

Untuk menilai kembali kinerja keuangan, perlu pemanfaatan sumber daya yang dimiliki oleh rumah sakit dan sumber daya yang ada disekitarnya dapat dimaanfaatkan semaksimal mungkin untuk pencapaian rencana-rencana kegiatan usahanya, dengan demikian penilaian kinerja itu sangat penting dilakukan.

Jika ditinjau dari aspek manajemen keuangan, BLU menerapkan manajemen bisnis dimana kegiatannya operasional BLU diarahkan pada praktek bisnis yang sehat. Tentu operasional manajemen keuangan BLU ini berbeda dengan satuan kerja yang murni menerapkan pola APBN/APBD. Walaupun manajemen keuangan BLU menerapkan manajemen bisnis yang sehat, tetapi BLU ini berbeda dengan BUMN/BUMD yaitu BLU tidak mengejar keuntungan (non profit oriented), sedangkan BUMN/BUMD merupakan badan usaha yang mengejar keuntungan. 
Pola pengelolaan yang berbasis praktek bisnis yang sehat yang berlaku pada sektorsektor yang terkait dalam operasional masing-masing BLU, tentunya akan berdampak pada peningkatan kinerja keuangan pada satuan-satuan kerja pemerintah yang telah menerapkan PPK-BLU, khususnya bagi RSUP Dr. Wahidin Sudirohusodo Makassar menerapkan standar akuntansi rumah sakit yang telah berlaku umum, dalam hal ini sesuai dengan standar akuntansi dari Ikatan Akuntan Indonesia. Meskipun demikian, sebagai salah satu satuan kerja di bawah Kementerian Kesehtan, RSUP Dr. Wahidin Sudirohusodo Makassar tetap mengkonsolidasikan laporan operasionalnya dengan laporan keuangan Kementerian Kesehatan, karena sebagian dana operasional dan investasi berasal dari dana APBN Kementerian Kesehatan, sebagai pertanggungjawaban Anggaran dan Belanja dari Kementerian Kesehatan. Persyaratan pendirian BLU meliputi tiga hal yakni persyaratan substantif, teknis dan administratif (Nurmandi, 2010).

Instansi BLU mempunyai sisi yang menarik untuk dikaji. Di satu sisi instansi yang menerapkan BLU merupakan instansi pemerintah yang menerapkan prinsi-prinsip manajemen bisnis yang sehat, dapat menggunakan langsung pendapatan untuk operasionalnya tanpa menyetor ke kas negara/ kas daerah dan surplus BLU yang diperoleh daapat digunakan untuk menambah penghasilan BLU. Tetapi di sisi lain instansi yang menerapkan PPK-BLU merupakan satuan kerja pemerintah yang merupakan satu kesatuan dengan kementerian/lembaga/pemerintah daerah.

RSUP Dr. Wahidin Sudirohusodo Makassar menjadi objek Penelitian dalam "Analisis Kinerja Keuangan pada Badan Layanan Umum (BLU) Rumah Sakit Umum Pusat Dr. Wahidin Sudirohusodo Makassar (setelah Implemnetasi PP 23 Tentang Pengelolaan Keuangan Badan Layanan Umum). Untuk melihat kinerja keuangan tersebut, maka kami memerlukan alat analisis rasio, yang menghubungkan data-data keuangan yang satu dengan yang lainnya.

Penelitian ini kami menggunakan Indikator rasio keuangan 6 (enam) berdasarkan Peraturan Direktur Jenderal Perbendaharaan Nomor: Per-36/PB/2012. Adapun indikator keuangan yang dimaksud adalah a) Rasio Kas (cash rasio) b) Rasio Lancar (current rasio) c) Periode Penagihan Piutang (collection period) d) Perputaran Aset Tetap (fixed asset turnover) e) Imbalan atas Aktiva Tetap ( return on asset) f) Imbalan Ekuitas (return on equity)

Kerangka konseptual dalam penelitian ini secara sederhana dapat digambarkan sebagai berikut : 


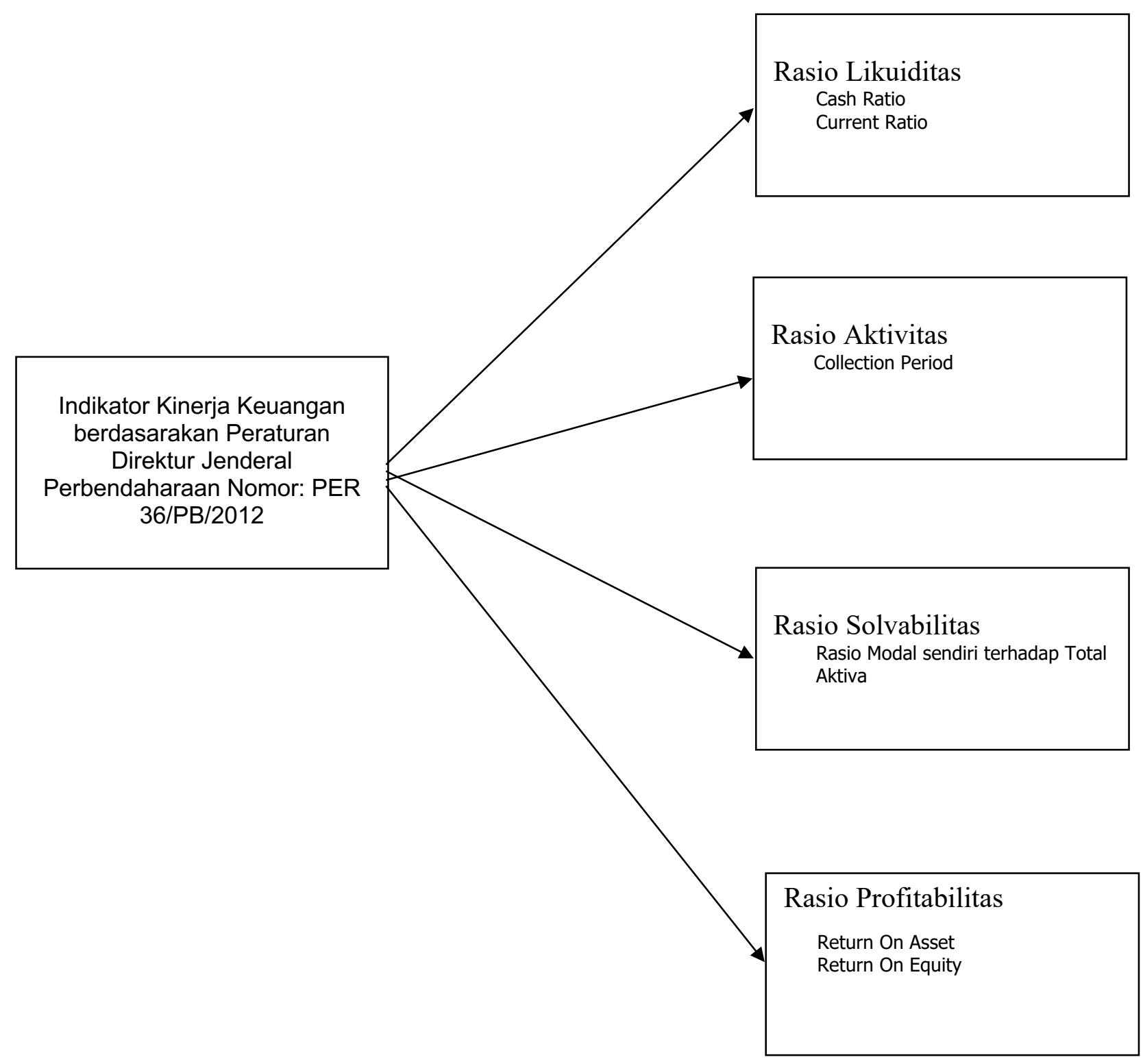

Berdasarkan uraian yang telah dikemukakan, maka diajukan hipotesis:

1. Rasio Likuiditas, Rasio Aktifitas, Solvabilitas dan Rasio Profitabilitas secara parsial mempunyai pengaruh signifikan terhadap Kinerja Keuangan Badan Layanan Umum RSUP Dr. Wahidin Sudirohusodo Makassar

2. Variabel Kinerja Keuangan RSUP Dr. Wahidin Sudirohusodo Makassar (Implementasi PP 23 Tahun 2005 tentang Pengelolaan Keuangan Badan Layanan Umum) adalah sehat. 


\section{METODE PENELITIAN}

Penelitian ini menggunakan pendekatan deduktif dan induktif. Pendekatan deduktif merupakan pendekatan secara teoritik untuk mendapatkan konfirmasi berdasarkan hipotesis dan observasi yang yang telah dilakukan sebelumnya. Pendekatan induktif merupakan pendekatan yang dilakukan untuk membangun sebuah teori berdasarkan hasil pengamatan atau observasi. Suatu observasi yang dilakukan berkali-kali akan membentuk pola tertentu

Untuk memperoleh data/informasi yang diperlukan penelitian ini, penulis mengumpulkan data melalui: Pengumpulan data berdasarkan dokumen-dokumen dan laporan-laporan keuangan RSUP Dr. Wahidin Sudirohusodo Makassar dari Tahun 2015 sampai dengan Tahun 2018 dan struktur organisasi (data sekunder) serta wawancara dengan pihak manajemen dan staf yang terkait dengan masaalah pokok (data primer)

Metode analisis yang akan digunakan oleh penulis dalam penelitian ini adalah metode analisis kuantitatif yaitu dengan menggunakan alat analisis yang dikenal sebagai Indikator rasio Keuangan berdasarkan Peraturan Direktur Jenderal Perbendaharaan Nomor: Per-36/PB/2012.

Analisis Rasio Keuangan adalah suatu metode analisis yang menjelaskan hubungan antara dua data keuangan. Data keuangan tersebut bersumber dari laporan keuangan, yakni neraca dan laporan surplus depisit. Ada 6 indikator rasio keuangan yang digunakan dalam penelitian ini yaitu: Rasio Kas (Cash Ratio); Rasio Lancar (Current Ratio); Periode Penagihan Piutang (Collection Period); Perputaran Aset Tetap (Fixed Asset Turnover); Imbalan atas Aktiva Tetap (Return on Asset); Imbalan Ekuitas (Return on Equity); adapun rumus-rumus dari tiap-tiap jenis yang digunakan dalam penelitian ini adalah sebagai berikut :

Rasio Keuangan dengan menggunakan indicator sebagai berikut :

a. Rasio Kas (Cash Ratio)

Rumus :

$$
\text { RK }=\frac{\text { Kas dan setara Kas }}{\text { Kewajiban Jangka Pendek }} \quad 100 \%
$$

b. Rasio Lancar (Current Ratio)

Rumus :

$$
\mathrm{RL}=\frac{\text { Aset Lancar }}{\text { Kewajiban Jangka Pendek }} \times 100 \%
$$

c. Periode renaginan rrutang (conection reriod)

Rumus ·

$$
\mathrm{PPP}=\frac{\text { Piutang Usaha }}{\text { Pendapatan Usaha }} \times 365 \text { hari }
$$


d. Perputaran Aset Tetap (Fixed Asset Turnover)

Rumus :

$$
\text { PAT }=\frac{\text { Pendapatan Operasional }}{\text { Asset Tetap }} \times 100 \%
$$

e. Imbalan atas Aktiva Tetap (Return on Asset)

Rumus :

$$
\mathrm{ROA}=\frac{\begin{array}{c}
\text { Surplus atau Defisit } \\
\text { sebelum Pos Keuntungan atau Kerugian }
\end{array}}{\text { Aset Tetap }} \times 100 \%
$$

f. Imbalan Ekuitas (Return on Equity)

Rumus :

Surplus atau Defisit

$$
\mathrm{ROE}=\frac{\text { sebelum Pos Keuntungan atau Kerugian }}{\text { Ekuitas }} \times 100 \%
$$

g. Rasio Pendapatan BLU terhadap Biaya Operasional

Rumus :

$\mathrm{PB}=$

Pendapatan BLU $\times 100 \%$

Biaya Operasioanal

\section{HASIL dan PEMBAHASAN}

\section{A. Deskripsi Hasil Penelitian}

Laporan keuangan RSUP Dr. Wahidin Sudirohusodo Makassar disusun dalam bentuk neraca dan laporan laba-rugi untuk setiap akhir periode/akhir tahun. Untuk tujuan analisis ini akan diperlihatkan laporan keuangan RSUP Dr. Wahidin Sudirohusodo Makassar, yang terdiri dari:

1. Neraca RSUP Dr. Wahidin Sudirohusodo Makassar per 31 Desember 2015 sampai dengan 31 Desember 2018.

2. Laporan rugi-laba RSUP Dr. Wahidin Sudirohusodo Makassar untuk tahun 2015 sampai dengan tahun 2018. 
Tabel 1. Laporan Neraca RSUP Dr Wahidin Sudirohusodo Makassar Periode 2015 S.D 2018

\begin{tabular}{|c|c|c|c|c|c|}
\hline \multirow{2}{*}{\multicolumn{2}{|c|}{ NAMA PERKIRAAN }} & \multicolumn{4}{|c|}{ TAHUN } \\
\hline & & \multirow[t]{2}{*}{2015} & \multirow[t]{2}{*}{2016} & \multirow[t]{2}{*}{2017} & \multirow[t]{2}{*}{2018} \\
\hline ASET & & & & & \\
\hline \multicolumn{6}{|c|}{ ASET LANCAR } \\
\hline & Kas pada Badan Layanan Umum & $55,305,126,828$ & $106,603,423,808$ & $105,590,669,218$ & $83,502,293,439$ \\
\hline & Piutang dari kegiatan Operasional Badan Layanan Umum & $36,030,050,588$ & $133,805,945,376$ & $130,618,559,144$ & $128,807,220,017$ \\
\hline & $\begin{array}{l}\text { Penyisihan Piutang Tidak Tertagih - Piutang dari Kegiatan } \\
\text { Operasional BLU }\end{array}$ & $(2,506,846,618)$ & $(5,000,859,681)$ & $(7,235,138,590)$ & $(8,624,652,638)$ \\
\hline & Piutang dari Kegiatan Operasional BLU (Netto) & $33,523,203,970$ & $128,805,085,695$ & $123,383,420,554$ & $120,182,567,379$ \\
\hline & $\begin{array}{l}\text { Piutang dari kegiatan Non Operasional Badan Layanan } \\
\text { Umum }\end{array}$ & $197,518,715$ & $140,729,488$ & $394,111,833$ & $213,884,544$ \\
\hline & $\begin{array}{l}\text { Penyisihan Piutang Tidak Tertagih - Piutang dari Kegiatan } \\
\text { Non Operasional BLU }\end{array}$ & $(987,594)$ & $(703,647)$ & $(1,970,559)$ & $(1,069,423)$ \\
\hline & $\begin{array}{l}\text { Piutang dari Kegiatan Non Operasional BLU } \\
\text { (Netto) }\end{array}$ & $196,531,121$ & $140,025,841$ & $392,141,274$ & $212,815,121$ \\
\hline & Persediaan & $34,094,021,923$ & $27,409,315,418$ & $31,066,012,406$ & $44,011,152,431$ \\
\hline & JUMLAH ASET LANCAR & $123,118,883,842$ & $262,957,850,762$ & $260,432,243,452$ & $247,908,828,370$ \\
\hline \multicolumn{6}{|c|}{ ASET TETAP } \\
\hline & Tanah & $85,777,504,000$ & $85,777,504,000$ & $861,190,516,000$ & $861,190,516,000$ \\
\hline & Peralatan dan Mesin & $415,937,267,676$ & $501,014,130,980$ & $561,052,375,328$ & $613,165,052,678$ \\
\hline & Gedung dan Bangunan & $230,366,459,991$ & $422,696,408,337$ & $452,370,437,191$ & $426,638,318,285$ \\
\hline & Jalan,Irigasi, dan Jaringan & $25,446,436,435$ & $27,480,523,185$ & $28,732,728,498$ & $28,801,554,998$ \\
\hline & Konstruksi Dalam Pengerjaan & $136,853,574,284$ & - & - & - \\
\hline & Aset Tetap Lainnya & - & - & - & $57,188,000$ \\
\hline & Akumulasi Penyusutan & $(346,180,979,943)$ & $(395,492,982,412)$ & $(413,749,570,564)$ & $(486,806,794,166)$ \\
\hline & JUMLAH ASET TETAP & $548,200,262,443$ & $641,475,584,090$ & $1,489,596,486,453$ & $1,443,045,835,795$ \\
\hline \multicolumn{6}{|c|}{ ASET LAINNYA } \\
\hline & Aset Tak Berwujud & $1,106,280,000$ & $1,106,280,000$ & $1,126,430,000$ & $1,126,430,000$ \\
\hline & Aset Lain-lain & $10,191,042,295$ & $19,494,261,870$ & $26,494,394,336$ & $14,988,503,650$ \\
\hline & Akumulasi Penyusutan/Amortisasi Aset Lainnya & $(10,178,313,895)$ & $(17,806,749,949)$ & $(25,436,516,105)$ & $(15,005,509,363)$ \\
\hline & JUMLAH ASET LAINNYA & $1,119,008,400$ & $2,793,791,921$ & $2,184,308,231$ & $1,109,424,287$ \\
\hline & JUMLAH ASET & $672,438,154,685$ & $907,227,226,773$ & $1,752,213,038,136$ & $1,692,064,088,452$ \\
\hline \multicolumn{6}{|c|}{ KEWAJIBA } \\
\hline \multicolumn{6}{|c|}{ KEWAJIBAN JANGKA PENDEK } \\
\hline & Utang kepada Pihak Ketiga & $25,118,090,457$ & $50,659,306,283$ & $48,653,379,631$ & $138,718,203,673$ \\
\hline & Pendapatan Diterima Di Muka & $407,675,000$ & $325,472,384$ & $504,127,050$ & $1,120,309,464$ \\
\hline & JUMLAH KEWAJIBAN JANGKA PENDEK & $25,525,765,457$ & $50,984,778,667$ & $49,157,506,681$ & $139,838,513,137$ \\
\hline & JUMLAH KEWAJIBAN & $25,525,765,457$ & $50,984,778,667$ & $49,157,506,681$ & $139,838,513,137$ \\
\hline \multicolumn{6}{|c|}{ EKUITAS } \\
\hline & Ekuitas & $646,912,389,228$ & $856,242,448,106$ & $1,703,055,531,455$ & $1,552,225,575,315$ \\
\hline & JUMLAH EKUITAS & $646,912,389,228$ & $856,242,448,106$ & $1,703,055,531,455$ & $1,552,225,575,315$ \\
\hline & JUMLAH KEWAJIBAN DAN EKUITAS & $672,438,154,685$ & $907,227,226,773$ & $1,752,213,038,136$ & $1,692,064,088,452$ \\
\hline
\end{tabular}


Tabel 2. Laporan Operasional RSUP Dr Wahidin Sudirohusodo Makassar Periode 2015 s/d 2018

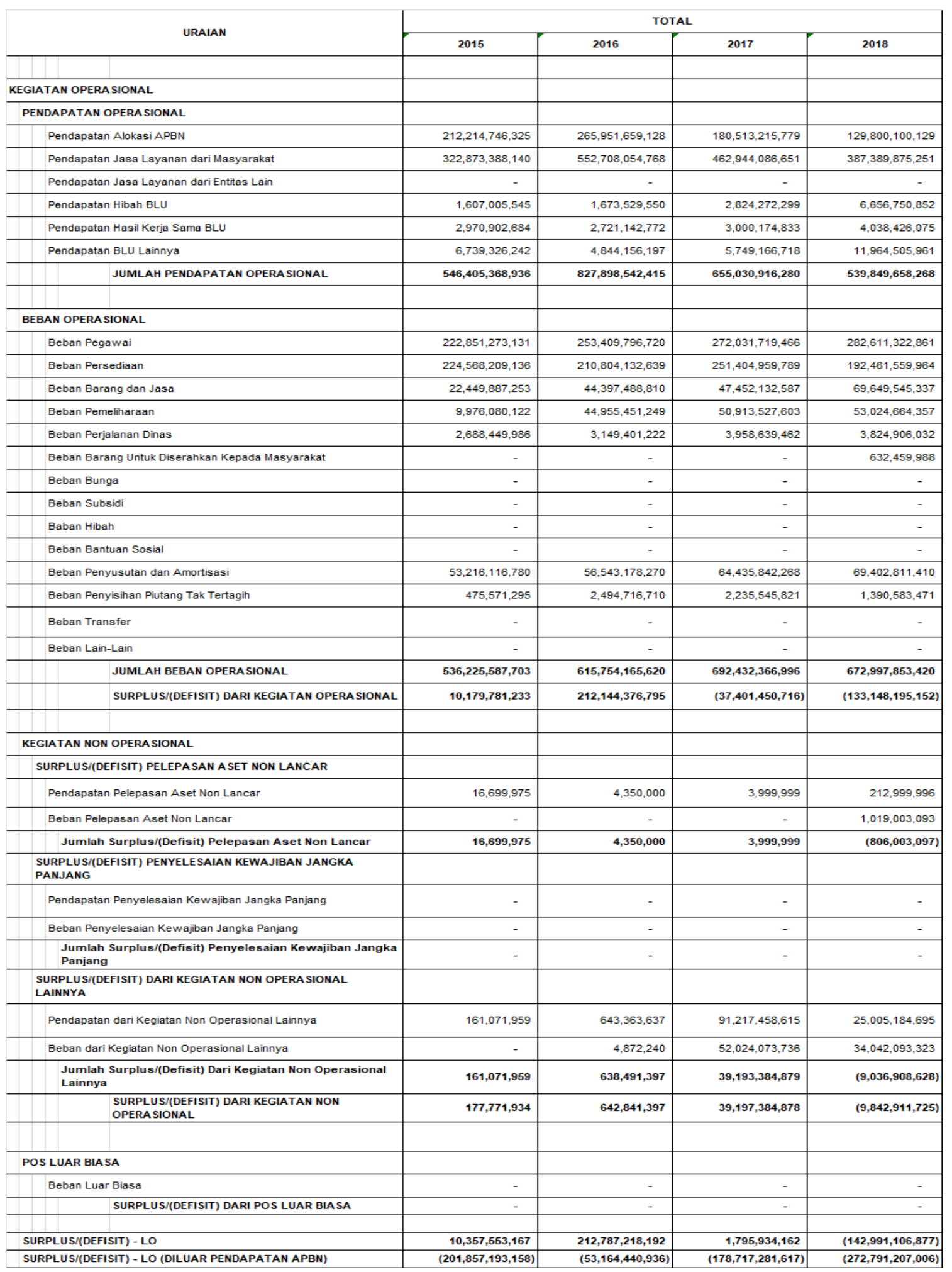

Berdasarkan data pada table 1 dan 2, nampak bahwa total aktiva, hutang, modal sendiri, dan pendapatan mengalami peningkatan setiap tahun selama tahun 2015 sampai 2018, sedangkan tingkat laba yang dicapai RSUP Dr. Wahidin Sudirohusodo 
Makassar mengalami fluktuasi selama tahun 2015 sampai 2018. Untuk lebih jelasnya akan diuraikan berikut ini.

Tabel 3. Rekapitulasi Analisis Rasio Keuangan pada RSUP Dr. Wahidin Sudirohusodo Makassar Tahun 2015-2018

\begin{tabular}{|c|c|c|c|c|c|c|c|c|}
\hline \multirow[t]{2}{*}{ Rasio Keuangan } & \multicolumn{4}{|c|}{ Tahun Buku } & \multirow[t]{2}{*}{$\begin{array}{l}\text { Rata- } \\
\text { rata }\end{array}$} & \multicolumn{2}{|c|}{$\begin{array}{c}\text { Penilaian Kinerja } \\
\text { Menurut } \\
\text { PER-36/PB/2012 }\end{array}$} & \multirow[t]{2}{*}{$\begin{array}{c}\text { Kategori } \\
\text { Penilaian } \\
\text { Kinerja }\end{array}$} \\
\hline & 2015 & 2016 & 2017 & 2018 & & Pengukuran & Skor & \\
\hline 1. Rasio kas (\%) & 220,18 & 210,43 & 217,03 & 60,20 & 176,96 & $176<\mathrm{RK} \leq 180$ & 4 & $\begin{array}{c}\text { Kurang } \\
\text { baik }\end{array}$ \\
\hline 2. Rasio lancar (\%) & 490,16 & 519,07 & 535,28 & 178,71 & 490,16 & $\begin{array}{l}490,16<\mathrm{RL} \leq \\
\quad 600\end{array}$ & 10,4 & Baik \\
\hline $\begin{array}{l}\text { 3. Periode } \\
\text { penagihan } \\
\text { piutang (hari) }\end{array}$ & 40,17 & 87,15 & 101,57 & 119,70 & 87,15 & $\begin{array}{c}87,15 \leq \mathrm{PPP}< \\
100\end{array}$ & 2 & $\begin{array}{c}\text { Kurang } \\
\text { baik }\end{array}$ \\
\hline $\begin{array}{l}\text { 4. Perputaran aset } \\
\text { tetap }(\%)\end{array}$ & 43,90 & 54,03 & 24,78 & 20,90 & 43,90 & $43,9<$ PAT & 10 & Baik \\
\hline $\begin{array}{l}\text { 5. Imbalan atas } \\
\text { aktiva tetap } \\
(\text { ROA) }(\%)\end{array}$ & $-5,57$ & 13,55 & $-0,70$ & $-4,29$ & 0,75 & $0<\mathrm{ROA} \leq 1$ & 0,5 & Tidak baik \\
\hline $\begin{array}{l}\text { 6. Imbalan ekuitas } \\
\text { (ROE) }(\%)\end{array}$ & $-6,63$ & 21,81 & $-0,76$ & $-4,91$ & 5,38 & $5<\mathrm{ROE} \leq 6$ & 3 & $\begin{array}{l}\text { Cukup } \\
\text { baik }\end{array}$ \\
\hline $\begin{array}{l}\text { 7. Rasio } \\
\text { pendapatan } \\
\text { PNBP terhadap } \\
\text { biaya } \\
\text { operasional }(\%)\end{array}$ & 69,19 & 100,49 & 75,56 & 67,93 & 78,29 & $78,29<\mathrm{PB}$ & 12 & Baik \\
\hline \multicolumn{6}{|c|}{$\begin{array}{l}\text { PENILAIAN KINERJA KEUANGAN RSUP Dr WAHIDIN } \\
\text { SUDIROHUSODO MAKASSAR TAHUN 2015-2018 }\end{array}$} & $\begin{array}{c}\text { Skor } \\
\text { maksimum } 65\end{array}$ & 41,9 & $\begin{array}{l}\text { Sedang } \\
\text { (B) }\end{array}$ \\
\hline
\end{tabular}

\section{B. Pembahasan}

Hasil analisis rasio keuangan menunjukkan bahwa kondisi keuangan dan perkembangan finansial RSUP Dr. Wahidin Sudirohusodo Makassar yang tergolong kurang baik selama tahun 2015-2018 adalah rasio kas, rasio lancar, dan periode penagihan piutang. Rata-rata nilai yang diperoleh dari hasil analisis rasio keuangan dari ketiga rasio keuangan tersebut berada di bawah nilai kisaran maksimum berdasarkan Peraturan Direktur Jenderal Perbendaharaan Nomor: PER-36/PB/2012 tentang Pedoman Penilaian Kinerja Keuangan Satuan Kerja Badan Layanan Umum. Persentase rasio kas (RK) sebesar 176,96\% dengan skor 4 dari skor maksimum 10 yang disyaratkan atau rata-rata nilai rasio kas tersebut berada di bawah nilai kisaran maksimum yang disyaratkan berdasarkan Peraturan Direktur Jenderal Perbendaharaan Nomor: PER-36/PB/2012 tentang Pedoman Penilaian Kinerja Keuangan Satuan Kerja Badan Layanan Umum. Dengan demikian, kondisi rasio kas tersebut tergolong kurang baik selama tahun 2015-2018, yang berarti bahwa RSUP 
Dr. Wahidin Sudirohusodo Makassar belum mampu melunasi hutang jangka pendeknya dengan kas yang dimilikinya, Oleh karena itu, rasio kas yang dicapai masih perlu ditingkatkan hingga mencapai skor maksimum dengan memberdayakan secara maksimal kas yang dimilikinya agar RSUP Dr. Wahidin Sudirohusodo Makassar memiliki kemampuan melunasi hutang jangka pendeknya guna mendukung peningkatan kinerja keuangan di masa akan datang.

Persentase rasio lancar 490,16 \% dengan skor 10,4 dari skor maksimum 13 yang disyaratkan, atau rata-rata nilai rasio lancar tersebut berada di bawah nilai kisaran maksimum yang disyaratkan berdasarkan Peraturan Direktur Jenderal Perbendaharaan Nomor: PER-36/PB/2012 tentang Pedoman Penilaian Kinerja Keuangan Satuan Kerja Badan Layanan Umum. Dengan demikian, kondisi rasio lancar tersebut tergolong baik selama tahun 2015-2018, yang berarti bahwa RSUP Dr. Wahidin Sudirohusodo Makassar mampu melunasi hutang jangka pendeknya dengan jaminan seluruh aktiva lancar yang dimilikinya. Oleh karena itu, rasio lancar yang dicapai tersebut masih perlu ditingkatkan hingga mencapai skor maksimum dengan memberdayakan secara maksimal seluruh aktiva lancar yang dimilikinya agar RSUP Dr. Wahidin Sudirohusodo Makassar memiliki kemampuan melunasi hutang jangka pendeknya guna mendukung peningkatan kinerja keuangan di masa akan datang.

Periode penagihan piutang selama 87 hari dengan skor 2 dari skor maksimum 10 yang disyaratkan atau rata-rata nilai rasio periode penagihan piutang tersebut berada di bawah nilai kisaran maksimum yang disyaratkan berdasarkan Peraturan Direktur Jenderal Perbendaharaan Nomor: PER-36/PB/2012 tentang Pedoman Penilaian Kinerja Keuangan Satuan Kerja Badan Layanan Umum. Dengan demikian, kondisi rasio periode penagihan piutang tersebut tergolong kurang baik selama tahun 2015-2018, yang berarti bahwa RSUP Dr. Wahidin Sudirohusodo Makassar belum mampu mengumpulkan piutang usaha dengan memaksimal seluruh pendapatan usaha yang dimilikinya, Oleh karena itu, rasio periode penagihan piutang yang dicapai tersebut masih perlu ditingkatkan hingga mencapai skor maksimum dengan memaksimal pengumpulan piutang usaha agar RSUP Dr. Wahidin Sudirohusodo Makassar memiliki kemampuan untuk mengumpulkan piutang usaha dengan cepat guna mendukung peningkatan kinerja keuangan di masa akan datang.

Rasio perputaran aset tetap (PAT) yang diperoleh sebesar 43,9\% dengan skor 10 dari skor maksimum 10 yang disyaratkan atau rata-rata nilai rasio lancar tersebut mencapai nilai kisaran maksimum berdasarkan Peraturan Direktur Jenderal Perbendaharaan Nomor: PER-36/PB/2012 tentang Pedoman Penilaian Kinerja Keuangan Satuan Kerja Badan Layanan Umum. Dengan demikian, kondisi rasio keuangan tersebut tergolong baik selama tahun 2015-2018, yang berarti bahwa RSUP Dr. Wahidin Sudirohusodo Makassar memiliki kemampuan menggunakan seluruh aktiva tetapnya untuk menghasilkan pendapatan guna mendukung peningkatan kinerja keuangan di masa akan datang.

Rasio Imbalan atas aktiva tetap (ROA) sebesar 0,75\% dengan skor 0,5 dari skor maksimum 5 yang disyaratkan, atau rata-rata nilai rasio ROA tersebut jauh di bawah nilai kisaran maksimum berdasarkan Peraturan Direktur Jenderal Perbendaharaan Nomor: PER-36/PB/2012 tentang Pedoman Penilaian Kinerja Keuangan Satuan Kerja Badan Layanan Umum. Dengan demikian, kondisi rasio keuangan tersebut 
tergolong tidak baik selama tahun 2015-2018, yang berarti bahwa RSUP Dr. Wahidin Sudirohusodo Makassar belum memiliki kemampuan dalam meningkatkan laba bersih dengan memberdayakan seluruh aktiva guna mendukung peningkatan kinerja keuangan di masa akan datang.

Rasio Imbalan ekuitas (ROE) sebesar 5,38\% dengan skor 3 dari skor maksimum 5 yang disyaratkan, atau rata-rata nilai rasio ROE tersebut belum mencapai nilai kisaran maksimum yang disyaratkan berdasarkan Peraturan Direktur Jenderal Perbendaharaan Nomor: PER-36/PB/2012 tentang Pedoman Penilaian Kinerja Keuangan Satuan Kerja Badan Layanan Umum. Dengan demikian, meskipun demikian kondisi rasio keuangan tersebut tergolong cukup baik selama tahun 20152018, yang berarti bahwa RSUP Dr. Wahidin Sudirohusodo Makassar memiliki kemampuan meningkatkan laba bersih dengan memberdayakan seluruh modal sendiri (ekuitas) guna mendukung peningkatan kinerja keuangan di masa akan datang.

Rasio pendapatan PNBP terhadap biaya operasional diperoleh sebesar 78,29\% dengan skor 12 yang disyaratkan, atau rata-rata nilai rasio keuangan tersebut telah mencapai nilai kisaran maksimum yang disyaratkan berdasarkan Peraturan Direktur Jenderal Perbendaharaan Nomor: PER-36/PB/2012 tentang Pedoman Penilaian Kinerja Keuangan Satuan Kerja Badan Layanan Umum. Dengan demikian, kondisi rasio pendapatan PNBP terhadap biaya operasional tergolong baik selama tahun 2015-2018, yang berarti bahwa RSUP Dr. Wahidin Sudirohusodo Makassar memiliki kemampuan meningkatkan pendapatan melalui penggunaan biaya yang efektif guna mendukung peningkatan kinerja keuangan di masa akan datang.

Hasil analisis rasio keuangan menunjukkan bahwa kondisi keuangan dan perkembangan finansial RSUP Dr. Wahidin Sudirohusodo Makassar yang tergolong baik selama tahun 2015-2018 adalah Rasio Lancar (RL), perputaran aset tetap (PAT), dan rasio pendapatan PNBP terhadap biaya operasional. Selanjutnya yang menunjukkan kondisi keuangan yang cukup baik adalah indikator pengukuran Imbalan ekuitas (ROE). Sedangkan yang menunjukkan kurang baik hingga tidak baik adalah pengukuran rasio kas, periode penagihan piutang, dan imbalan atas aktiva tetap (ROA), sehingga perlu mengefektifkan pemberdayaan kas dan aktiva, serta penagihan piutanng agar diperoleh rasio keuangan mendekati atau mencapai nilai kisaran maksimum yang disyaratkan berdasarkan Peraturan Direktur Jenderal Perbendaharaan Nomor: PER-36/PB/2012 tentang Pedoman Penilaian Kinerja Keuangan Satuan Kerja Badan Layanan Umum.

Sehubungan dengan penilaian kinerja keuangan di bidang layanan kesehatan untuk rasio keuangan dan pendapatan BLU secara keseluruhan dengan bobot maksimum 65 berdasarkan Peraturan Direktur Jenderal Perbendaharaan Nomor: PER-36/PB/2012 tentang Pedoman Penilaian Kinerja Keuangan Satuan Kerja Badan Layanan Umum, menunjukkan bahwa RSUP Dr. Wahidin Sudirohusodo Makassar yang memiliki nilai rasio keuangan dan pendapatan PNBP secara keseluruhan adalah $41,9 \%$ dengan predikat penilaian kinerja keuangan digolongkan dalam klasifikasi "Sedang" atau kategori B (apabila $40<$ Total Skor < 50) karena nilai rasio tersebut berada di bawah rata-rata dari bobot maksimum yang disyaratkan yakni bobot 65. Oleh karena itu, kinerja keuangan pada RSUP Dr. Wahidin Sudirohusodo Makassar yang tergolong klasifikasi "Sedang" atau cukup sehat, sehingga masih perlu ditingkatkan terutama yang terkait dengan mengefektifkan penggunaan kas, 
penagihan hutang, dan lebih memberdayakan seluruh aktiva dan modal sendiri dalam meningkatan laba serta pemanfaatan biaya operasional dipergunakan secara efektif guna mendukung peningkatan kinerja keuangan di masa akan datang. Penilaian kinerja keuangan selama tahun 2015 sampai 2018 tergolong kurang sehat, sehingga indiaktor-indikator pengukuran kinerja keuangan perlu diberdayakan secara maksimal agar dapat memberikan kontribusi yang besar terhadap peningkatan laba pada RSUP Dr. Wahidin Sudirohusodo Makassar di masa akan datang

\section{KESIMPULAN}

Berdasarkan hasil penelitian, hasil analisis nilai rasio keuangan selama tahun 2015 sampai 2018 menunjukkan bahwa kinerja keuangan pada RSUP Dr. Wahidin Sudirohusodo Makassar tergolong "cukup baik", dimana kondisi rasio keuangan yang tergolong baik hanya terdapat pada Rasio Lancar (RL), perputaran aset tetap (PAT), dan rasio pendapatan PNBP terhadap biaya operasional, dan yang menunjukkan kondisi keuangan yang cukup baik adalah Imbalan ekuitas (ROE), serta yang menunjukkan kurang baik hingga tidak baik adalah pengukuran rasio kas, periode penagihan piutang, dan imbalan atas aktiva tetap (ROA). Sedangkan hasil analisis nilai rasio keuangan dan pendapatan PNBP secara keseluruhan selama tahun 2015 sampai 2018 menunjukkan bahwa kinerja keuangan pada RSUP Dr. Wahidin Sudirohusodo Makassar tergolong "cukup sehat" karena nilai rasio mencapai 41,9 dengan predikat penilaian kinerja keuangan berada pada klasifikasi "Sedang" atau kategori B (apabila $40<$ Total Skor < 50) dimana nilai rasio tersebut berada di atas rata-rata dari bobot maksimum yang disyaratkan yakni bobot 65 .

Hasil penelitian ini menyarankan agar kinerja keuangan RSUP Dr. Wahidin Sudirohusodo Makassar masih perlu ditingkatkan, dengan mengefektifkan penggunaan kas, dan seluruh aktiva lancar, serta mampu pengumpulan piutang dengan cepat agar kinerja keuangan dapat ditingkatkan di masa akan datang. Diperlukan upaya meningkatkan laba RSUP Dr. Wahidin Sudirohusodo Makassar melalui peningkatan pendapatan dan menekan biaya-biaya operasional agar kinerja perusahaan dapat ditingkatkan atau lebih bagus dari sebelumnya. Kinerja keuangan RSUP Dr. Wahidin Sudirohusodo Makassar yang tergolong tidak baik dan kurang baik agar lebih diefektifkan lagi pemberdayaannya terutama yang terkait dengan kas dan seluruh aktiva guna mendukung peningkatan kinerja keuangan agar berada pada kategori "sehat" di masa akan datang.

\section{DAFTAR PUSTAKA}

Peraturan Pemerintah Republik Indonesia Nomor: 23 Tahun 2005 tentang Pengelolaan Keuangan Badan Layanan Umum, Jakarta

Peraturan Direktur Jenderal Perbendaharaan Nomor: PER -36/PB/2012 tentang Pedoman Penilaian Kinerja Keuangan Satuan Kerja Badan Layanan Umum; 
Peraturan Menteri Keuangan RI Nomor: 190/PMK.05/2012 tentang Tata Cara Pembayaran Dalam rangka Pelaksanaan Anggaran pendapatan dan Belanja Negara.

Peraturan Menteri Keuangan Nomor: 76/PMK.05/2008 tentang Pedoman Akuntansi Badan Layanan Umum

Peraturan Pemerintah Nomor 24 Tahun 2005 tentang Standar Akuntansi Pemerintahan.

Undang-Undang Nomor 1 Tahun 2004 tentang Perbendaharaan Negara.

Undang-Undang Nomor 15 Tahun 2005 tentang Pemeriksaan Keuangan Negara

Undang-Undang Nomor 17 Tahun 2003 tentang keuangan negara

Undang-undang Nomor: 44 Tahun 2009 tentang Rumah Sakit, Jakarta

Cascio, Wayney. (1992). Managing Human Resource. International Edition, McGraw Hill Inc

Depkes, Ditjen Yanmed, (1994). Informasi Rumah Sakit, Departemen Kesehatan RI, Jakarta

Erich A, Helfert, (1997). Teknik-teknik Analisis Keuangan, Petunjuk Praktis untuk Mengelola dan mengukur Kinerja Perusahaan. Terjemahan Herman Wibowo, Edisi Kedelapan, Erlangga, Jakarta.

Fahmi, Irham. 2011. Analisis Laporan Keuangan. Lampulo: ALFABETA.

Gibson, Charles H, (1989). Financial Statement Analysis. Using Financial Accounting Information, Fourth Edition. PWS-Kent Publishing Company, Boston.

G.Foster, (1986). Financial Statement Analysis, Second Edition, Stanford Ford University, Prentice-Hall International, New Jersey, USA

Hanafi, Mamduh M, dan Halim, Abdul, (2009). Analisis Laporan Keuangan, Edisi Keempat, UPP STIM YKPN, Yogyakarta.

Hilmy, (2003). “Analisis Kinerja keuangan Rumah Sakit Dr. Wahidin Sudirohusodo Makassar" Universitas Hasanuddin, Makassar

Hery. (2015). Analisis Laporan Keuangan- Integrated and Comprehensive Edition. Penerbit: Grasindo

Ikatan Akuntansi Indonesia, (1994). Prinsip Akuntansi Indonesia, 1994 Edisi Revisi II, Rineka Cipta, Jakarta.

Ikatan Akuntan Indonesia. (2015). Standar Akuntansi Keuangan (SAK). Jakarta: Salemba Empat

Jumingan. (2013). Analisis Laporan Keuangan. Jakarta: Bumi Aksara

Kasmir. (2010). Analisis Laporan Keuangan. Edisi Satu. Cetakan Ketujuh. Jakarta: PT Raja Grafindo Persada.

Kasmir. 2012. Analisis Laporan Keuangan. Jakarta: PT. Raja Grafindo Persada. 
Munawir, S., (1997). Analisa Laporan Keuangan, Edisi Keempat, Penerbit Liberty, Yogyakarta

Munawir, S. (2012). Analisis Informasi Keuangan, Liberty, Yogyakarta.

Muhammad Karya Satya Azhar, (2010). “Analisis Kinerja Keuangan Pemerintah Daerah Kabupaten/Kota Sebelum dan Setelah Otonomi Daerah" Dosen STIE Harapan Medan. Medan.

Sutrisno, (2000). Analisis Kinerja Keuangan dan Perencanaan Keuangan Perusahaan, Penerbit Gramedia Pustaka Utama, Jakarta 